\title{
A Casebook for the Dean's Reading List: Holland, McAllister, Shaman \& Sutton, State Constitutional Law: The Modern Experience
}

\author{
Allen L. Lanstra ${ }^{*}$
}

I. INTRODUCTION

Perhaps this Article will prompt you to obtain a professor's review copy of its subject-the new casebook, State Constitutional Law: The Modern Experience ${ }^{1}$ - and present it to the dean or academic dean of your law college. If you share my distress about the comparative silence of law schools and bar examiners in response to the contemporary callings to teach and test state constitutional law, ${ }^{2}$ consider also attaching a copy of co-author and Sixth Circuit Judge Jeffrey S. Sutton's article, Why Teach-and Why Study-State Constitutional Law, ${ }^{3}$ or flagging retired Delaware Supreme Court Chief Justice E. Norman Veasey's Foreword to The Modern Experience, which culminates in a reprint of the July 2010 Conference of Chief Justices Resolution regarding State Constitutional Law Courses.

For too long, the American legal educational system has ignored the importance of state constitutions to our legal and political systems. Scholarly commentary from United States Supreme Court Justice William J. Brennan Jr. and Oregon Supreme Court Justice Hans A. Linde in the late 1970s and early 1980s raised attention to the dormancy of state constitutional law and seemingly led to the development of the first and, until now, only employed casebook on the subject. ${ }^{4}$ Although that

* Trial and Appellate Attorney, Skadden, Arps, Slate, Meagher \& Flom; Adjunct Professor of Law, Loyola Law School Los Angeles; J.D., Michigan State University College of Law; M.S., Walsh College; B.A., Michigan State University.

1. Randy J. Holland, Stephen R. McAllister, Jeffrey M. Shaman \& Jeffrey S. Sutton, State Constitutional LAW: THE MODERn EXPERIENCE (2010).

2. See Allen L. Lanstra, A Modern Constitutional Crisis, L.A. DAILY J., Nov. 30, 2010, at 6.

3. Jeffrey S. Sutton, Speech, Why Teach-and Why Study-State Constitutional Law, 34 OKLA. CITY U. L. REV. 165 (2009).

4. See Robert F. Williams, State Constitutional Law: Cases and Materials (4th ed. 2006). 
casebook has been around for about two decades now, state constitutional law remains obscure. This needs to change.

The Modern Experience is an agent of that change. It supplies a thorough learning tool that holds the promise of advancing the teaching of state constitutional law in our nation's law schools. In my opinion, it provides a much-needed fresh approach to the subject that emphasizes not only the relevant doctrines and structural underpinnings of the role of state constitutional law in our federalist system, but also the real-lawyer, practical applications of state constitutional law. Law professors and academic deans should strongly consider adding state constitutional law to the curriculum. The Modern Experience is poised to serve as an excellent platform for the course.

\section{THE AUTHORS}

The collective professional experience of the authors of The Modern Experience supplies a balanced approach to a subject matter that is weighted with constitutional theory and doctrine but also begs for recognition of its undeniable application in practice. Indeed, by way of their contribution, the authors have noticeably attempted to remedy the all-too-common misnomer that state constitutions add very little to the body of American constitutional law.

Randy J. Holland serves on the Delaware Supreme Court. ${ }^{5}$ Prior to his initial appointment and confirmation in 1986, Justice Holland was in private practice as a partner at Morris, Nichols, Arsht \& Tunnell. Justice Holland also earned a Master of Laws in the Judicial Process from the University of Virginia School of Law, where his culminating thesis focused on state constitutional history. In addition to The Modern Experience, Justice Holland has written, co-authored, or edited five other law books. ${ }^{6}$

Stephen R. McAllister is Professor of Law at the University of Kansas School of Law, where he teaches constitutional law and

5. Judicial Officers of the Delaware Supreme Court, Del. STATE CouRTS, http://courts. delaware.gov/supreme/justices.stm (last visited Apr. 5, 2011).

6. ERIC StOcKDale \& RANDy J. Holland, Middle Temple LaWyers AND tHe AMERICAN REVOlution (2007); Robert J. MARTINEAU, Kent Sinclair, MichaEl E. SOlimine \& RANDY J. Holland, Appellate Practice and Procedure (2d ed. 2005); Randy J. Holland, The Delaware State Constitution: A Reference Guide (2002); Delaware Supreme Court: Golden ANNIVERSARY 1951-2001 (Randy J. Holland \& Helen L. Winslow eds., 2001); THE DELAWARE CONSTITUTION OF 1897: The FIRST ONE HundRED YeARS (Randy J. Holland et al. eds., 1997). 
previously served as dean. ${ }^{7}$ He boasts one of the country's most prestigious clerking resumes, having clerked for Justices Byron White and Clarence Thomas of the Supreme Court of the United States and Judge Richard Posner of the United States Court of Appeals for the Seventh Circuit. ${ }^{8}$ His work has been published extensively, ${ }^{9}$ and he has worked both in private practice and as Solicitor General for the State of Kansas.

Jeffrey M. Shaman is the Vincent de Paul Professor of Law at the DePaul University College of Law, where his teaching and scholarship concentrate on constitutional law and judicial ethics. ${ }^{10}$ He is a prolific constitutional law author. In addition to The Modern Experience, Professor Shaman has published numerous other books. ${ }^{11}$ He also teaches state constitutional law and has written on the subject. ${ }^{12}$

Jeffrey S. Sutton serves on the United States Court of Appeals for the Sixth Circuit. ${ }^{13}$ Prior to his appointment to the bench, Judge Sutton was

7. Biography of Stephen R. McAllister, K.U. SCHOOL OF LAw, http://www.law.ku.edu/ kulaw/ faculty/faculty/mcallister.shtml (last visited Apr. 5, 2011).

8. Id.

9. See Stephen R. McAllister, Ask the State Solicitor General: Can the State File a "Reply" Brief When It Takes an Exception in an Original Jurisdiction Case in the Supreme Court of the United States?, 29 ReV. LiTIG. 537 (2010); Stephen R. McAllister, The Supreme Court's Treatment of Sovereigns as Amici Curiae, 13 GREEn BAG 2D 289 (2010); Stephen R. McAllister, Can Congress Create Procedures for the Supreme Court's Original Jurisdiction Cases?, 12 GREEN BAG 2D 287 (2009); Stephen R. McAllister, Funeral Picketing Laws and Free Speech, 55 U. KAN. L. REv. 575 (2007); Stephen R. McAllister, “Insider” Deaning, 34 U. Tol. L. REV. 121 (2002); Stephen R. McAllister, Some Reflections on the Constitutionality of Sex Offender Commitment Laws, 50 U. KAN. L. REV. 1011 (2002); Stephen R. McAllister, "Neighbors Beware": The Constitutionality of State Sex Offender Registration and Community Notification Laws, 29 TeX. TECH L. REV. 97 (1998); Stephen R. McAllister, A Pragmatic Approach to the Eighth Amendment and Punitive Damages, 43 U. KAN. L. Rev. 761 (1995); Stephen R. McAllister, The Problem of Implementing a Constitutional System of Capital Punishment, 43 U. KAN. L. REv. 1039 (1995); Stephen R. McAllister, Sex Offenders and Mental Illness: A Lesson in Federalism and the Separation of Powers, 4 PsYCHOL. PUB. POL'Y \& L. 1 (1998).

10. Biography of Jeffrey M. Shaman, DePaUl COLLEGE OF LAW, http://www.law.depaul.edu/ faculty_staff/faculty_information.asp?id=36 (last visited Apr. 5, 2011).

11. See Jeffrey M. Shaman, Equality and Liberty in the Golden Age of State CONSTitutional LAW (2008); JAMES J. Alfini, STEVEn Lubet, JEFFREy M. SHAMAN \& CHARLES GARDNER GeYh, JUdicial CONDUCT AND ETHics (4th ed. 2007); JEFFREy M. SHAMAN, CONSTITUTIONAL INTERPRETATION: ILLUSION AND REALITY (2001); JEFFREY M. SHAMAN \& JONA GOLDSCHMidT, JUdiCIAL DisQUALIFICATION: AN EMPIRICAL STUDY OF JUDICIAL PRACTICES AND AtTitudes (1995); JeFFrey M. Shaman \& CyNTHia Gray, Judicial ConduCt \& ETHics CuRriculum (1993); RICHARD C. TURKINGTON \& JEFFREY M. SHAMAN, CASES AND MATERIALS on the Constitutional PRocess (2d ed. 1975).

12. See Jeffrey M. Shaman, The Right of Privacy in State Constitutional Law, 37 RUTGERS L.J. 971 (2006); Jeffrey M. Shaman, The Evolution of Equality in State Constitutional Law, 34 RUTGERS L.J. 1013 (2003).

13. Jeffrey S. Sutton, HISTORY OF THE SiXTH CIRCUIT, http://www.ca6.uscourts.gov/lib_hist/ 
in private practice at Jones, Day, Reavis \& Pogue and served as the State Solicitor General of Ohio. ${ }^{14}$ He clerked for Judge Thomas Meskill of the United States Court of Appeals for the Second Circuit and United States Supreme Court Justices Lewis Powell and Antonin Scalia. ${ }^{15}$ Judge Sutton writes on and teaches, among other subjects, state constitutional law. $^{16}$

\section{SCOPE AND COVERAGE}

The casebook's sixteen chapters are reasonable in length and aptly cover the array of issues suitable for either a two- or three-credit, upperlevel course. Before the co-authors interject the classroom into the substance of the subject matter, the Foreword by the former Chief Justice of the Delaware Supreme Court, E. Norman Veasey, delivers a reassuring message about the importance of the study of state constitutional law, which is further embraced by the short Introduction comprising Chapter $1 .^{17}$

Chapter 2 introduces students to the framing of state constitutions by setting forth their history. Substantively, the co-authors hit the mark by focusing on state constitutional history as it underscores several hallmarks of the subject. First, state constitutions provided the structural foundation for the Federal Constitution, not vice versa. The states began the experiment and students can learn to appreciate that the primary accomplishment of the Founders was their ability to reach a compromise between thirteen sovereigns and to adjust their prior compact, the Articles of Confederation. It was the state constitutional conventions, particularly those in Virginia, Massachusetts and Pennsylvania, where the concepts of the American form of constitutional government was born. Second, unlike the U.S. Constitution, state constitutions often have declarations of rights at the beginning of their compacts. The protection of rights by state constitutions is a theme revisited throughout The Modern Experience. Third, our state constitutions have served as instruments of leadership in many areas, such as direct democracy and the election of judges, and have been forced to adapt to legal and

Courts/circuit/judges/judges/jss-bio.html (last visited Apr. 5, 2011).

14. Id.

15. Id.

16. Id.

17. I require all my students to read the forewords, summary of contents and introductions in each casebook, which serve as foundational reading for my first question on almost every case we study: "Why did the author put this case in the book?" 
historical events, such as Reconstruction, congressional control over western expansion, and the impact of the incorporation doctrine and the Fourteenth Amendment on dual sovereignty principles.

In my opinion, the authors also made a wise choice by presenting the all-important history section by way of a single excerpt. Not only is Justice Holland's thesis well-researched and well-written, its cohesiveness (embraced by plenty of citations and references for those with an encouraged appetite) permits a level of student absorption often inhibited by miscellaneous book and article excerpts presented in a disjointed form.

Chapter 3 addresses dual sovereignty, which runs through the heart of the course. Its placement in the casebook is fitting. An elementary principle that is foreign to students blinded by their study of federal constitutional law, but also critical to a true understanding of state constitutional law, is that while Congress is granted certain limited and enumerated powers through the Federal Constitution, state legislatures operate through constitutions that limit their plenary power and impose mandates on them. Against this backdrop, the chapter confronts the division of sovereign power as addressed by Articles IV and VI of the U.S. Constitution and case law delineating certain exclusive and shared powers.

Chapter 4 introduces students to the art and science of interpretation in the context of state constitutional provisions. It is an excellent contribution to classroom discussion of state constitutional law. In addition to tackling the jurisdictional angle of independent and adequate state grounds, the authors included several cases that demonstrate theories by which state constitutional provisions can be and are interpreted differently than comparable federal constitutional provisions, including where the text is similar or distinct. The strict employment of the case law method here, fortified by use of the Socratic method, has the potential to invite embattled class discussions wherein students will struggle to identify their own views of both constitutional interpretation and the role of state constitutions in our dual-sovereign system of governance.

Chapters 5 through 13 can be a course by themselves, as they focus on the individual rights and protections found in state constitutions: equal protection (Chapter 5), due process of law (Chapter 6), criminal procedure (Chapter 7 ), search and seizure (Chapter 8 ), property rights (Chapter 9), religion (Chapter 10), school funding (Chapter 11), the right to a remedy and open courts (Chapter 12), and the rights of privacy, free speech, to bear arms, crime victims' rights and punitive damages (Chapter 13). Many of these topics form the breeding ground for our 
country's most prominent state court battles on contemporary political issues, such as affirmative action, same-sex marriage, and abortion.

These chapters must live and die on the cases contained therein. Yet the authors have done a formidable job of accomplishing two essential goals for these chapters. First, the cases demonstrate that state constitutions may afford rights and guarantees beyond those provided by the U.S. Constitution and, indeed, that is precisely how many rights have been extended or expanded in our country. Second, states take different approaches to various rights, caused by variances in political preference, the power of direct democracy, judicial interpretation and, in many instances, simply local custom. In short, the states are true laboratories for constitutional liberties.

Chapter 14 is law without the flash and thus may not attract the love of students, but its teachings are integral to a complete understanding of the practice of state constitutional law. The authors have located excellent case law to demonstrate the unique state constitutional provisions concerning single-subject rules, clear title rules, public purpose requirements, and uniformity clauses in state legislation. These are limits on legislative authority that belong in the arsenal of any state law practitioner.

Chapter 15 covers the organization of state governments and is state political science in many ways. However, for a practicing attorney, there are many important distinctions that should be learned-particularly as to the judicial branch. State judges are often elected in some form, and state courts may also be permitted to render advisory opinions and answer certified questions.

The casebook ends with Chapter 16, which addresses the unique constitutional issue of initiatives and referenda that exists in about half of the states. This can be an exciting chapter for students as they can seriously envision themselves engaging in the practice of law in a way that leads to direct legislative and constitutional change. Discussions about constitutional conventions, a reality at least when compared to such opportunities under the Federal Constitution, also can invite spirited discussion.

\section{CONCLUSION}

Justice Holland, Professor McAllister, Professor Shaman, and Judge Sutton have developed an interesting, well-written casebook that accomplishes the scholastic goal of teaching the principles of state constitutional law while presenting it in a form that teaches students about the practical application of the subject matter. The result is a 
casebook that affords students an academic experience accompanied by an appreciation for the ingredients of innovative legal argument. Law colleges that add state constitutional law to the curriculum will help produce better-equipped practitioners and aid their students in fulfilling the obligations undertaken by each lawyer, namely to uphold both the federal and state constitutions. 